\title{
Mixed Red Ginger (zingiber offinale var rubrum) with Turmeric (curcuma longa) as Feed Additive to Improve Conversion Meat Protein Broiler
}

\author{
Tuti Widjastuti $^{* *}$, Dani Garnida ${ }^{1}$, Wiwin Tanwiriah ${ }^{1}$ and Roostita L. Balia ${ }^{1}$
}

Date Received: $18^{\text {th }}$ December 2019 / Date Accepted: $26^{\text {th }}$ January 2020

\begin{abstract}
Purpose : The purpose of this study was to determine the optimal levels of a mixture of red ginger and turmeric meal with a ratio of $1: 1$ as feed additive on the conversion meat protein broiler.

Research Method: This study used 100 DOC broiler chickens that were kept until 35 days old. The experimental design used was a CRD with 4 treatment levels and five replications each. The treatments consisted of PO (basal ration without a mixture of red ginger and turmeric meal), $P 1=0.5 \%$ mixture red ginger and turmeric meal, $P 2=$ $1 \%$ mixture red ginger and turmeric meal and $P 3=1.5 \%$ mixture red ginger and turmeric meal. The parameters observed were protein consumption, body weight gain, protein conversion, and meat protein conversion.

Findings : Research showed that the P1 and P2 were not significantly different from the conversion value of meat protein but the meat protein conversion value was significantly lower compared to treatment $P 0$ and $P 3$. This finding indicates that diet given that contains a mixture of red ginger and turmeric meal $1 \%$ (P2) were still able to support the good result to meat protein conversion value of broiler.

Value : It is better to maintain broiler with a mixture of turmeric and ginger $1 \%$ and in order to produce a profitable maintenance, this is a useful evidence for breeders and animal husbandry experts.
\end{abstract}

Keywords: Conversion meat protein, feed additive, red ginger, turmeric

\section{INTRODUCTION}

Broiler chicken is a type of meat-producing chickens that is commonly cultivated in Indonesia. Calculated fast and can be harvested at the age of 35 days. For the betterment, broiler chicken must also be supported by quality ration and good maintenance management. Even good quality rations are still inadequate to increase growth and therefore, also in broiler rations they are given relatively small amounts of ingredients and additives to stimulate chicken growth called feed additives (feed additives). In addition to these advantages, broiler chickens also have weaknesses, including being vulnerable to disease. Therefore, it is necessary to look for herbal feed additives (fitofarmaka) that can improve digestive performance to improve animal health to increase the efficiency of ration.

Herbal ingredients commonly used like, red ginger (Zingiber officinale Var Rubrum) and turmeric (Curcuma longa). According to A. Kafi et al, (2017) nine composites found in ginger may bind to serotonin receptors which may affect gastrointestinal function. Red Ginger contains bioactive components in the form of essential oleoresin and gingerol which function to help in optimizing the function of body organs to stimulate the digestive system by controlling $\mathrm{pH}$, enzyme activity and microbial activity. Atsiri oils help the work of digestive enzymes so that the rate of feed increases and meat production will rise. The stimulation of the intestinal mucous membrane by atsiri oils released by ginger will cause the stomach to become empty and livestock will consume food. Atsiri oil from red ginger is believed

\footnotetext{
I* Faculty of Animal Husbandry, Universitas Padjadjaran, Jalan Raya Bandung-Sumedang Km 21, 45363, Sumedang-West Java, Indonesia.

tuti_widjstuti@yahoo.com
}

(D) ORCID http://orcid.org/0000-0003-1437-5164 
to have properties to inhibit the growth of microorganisms (Tuti et al., 2017).

The nature of gingerol as an anticoagulant that can prevent blood clots, is also expected to reduce cholesterol levels. Whilst turmeric is a type of plant that can be used to replace synthetic antibiotics, because it contains active compounds namely, curcumin and atsiri oils. Curcumin increases production levels and expedites bile secretion or can stimulate bile excretion so that it can digest fat properly and the content of essential oils is antibacterial to gram-positive or negative. According to Kunnumakkara et al, (2017) more than sixty active compounds have been isolated and identified from turmeric. Curcumin could be a potential feed additive that increased the oxidant stability of muscle and the meat quality in broiler chickens. The content of turmeric curcumin has the function as an antibacterial and antioxidant. Curcumin contained in turmeric has properties that can affect appetite because it can accelerate the emptying of gastric contents so that appetite increases and expediting bile expenditure thereby increasing digestive tract activity (Indrawati et al., 2018).

The higher the content of ginger and turmeric in the ration, the higher the effects of the colleague produced so that it will stimulate the bile to secrete bile, resulting in the more efficient digestion of proteins, fats, and carbohydrates (Z.A. Sa'aci et al., 2018). The addition of red ginger rhizome flour and turmeric indirectly affects the consumption of feed and absorption of food substances so that it can form meat production and the percentage of carcasses will increase.The use of a mixture of red ginger and turmeric in the ration as a feed additive that will increase digestion, can especially increase the metabolism of protein and fat so that meat conversion is expected to be increased. The resulting weight gain is a description of the quality of the ration given. One way to assess the quality of the ration is to calculate the value of protein conversion and meat protein conversion. Protein conversion is defined as protein consumption divided by weight gain. Meanwhile the conversion of livestock protein determines the level of efficiency of livestock in changing every gram of protein to how much meat is produced. This research is aimed to study the " Mixed red ginger (zingiber offinale var rubrum) with turmeric (curcuma longa) as feed additive to improve conversion meat protein broiler".

\section{MATERIAL AND METHOD}

The study used 100 day- old broilers that were kept in deep litter system until the age of 5 weeks. 20 pens were used, sized 1 x 1 x 0.60 $\mathrm{m}$, and each unit consisted of five chickens. The experimental design used was Completely Randomized Design with 5 treatment levels of turmeric extract, and 4 replications respectively. The feed ingredients used for ration consist of yellow corn (56\%), soybean meal (22\%), fish meal $(3 \%)$, corn glutean meal $(12,5 \%)$, meat bone meal $(4,5 \%)$, salt $(0,2 \%)$, top mix $(0,5 \%)$, lysin $(0,2 \%)$, methionine $(0,1 \%)$ and bone meal (1\%). The rationing for broilers contains $22 \%$ protein and $3000 \mathrm{kcal} / \mathrm{kg}$ of metabolic energy.

The given treatment was the addition of a mixture of red ginger and turmeric meal as feed additives in broiler chicken rations. The treatments are $\mathrm{P}_{0}$ (basal ration without a mixture of red ginger and turmeric meal), $\mathrm{P}_{1}$ $(0.5 \%$ mixture of red ginger + turmeric meal $)$, $\mathrm{P}_{2}(1 \%$ mixture of red ginger + turmeric meal $)$, and $\mathrm{P}_{3}(1.5 \%$ mixture of red ginger + turmeric meal). The parameters observed were protein consumption, body weight gain, protein conversion, and meat protein conversion. Data were analyzed using Variance Analysis and differences between treatments using Duncan Multiple Test. The study was conducted in the research cage, poultry laboratory of the Faculty of Animal Husbandry Universitas Padjadjaran, Jatinangor.

\section{RESULT AND DISCUSSION}

The protein consumption, body weight gain, protein conversion and meat protein were influences significantly by additional of feed additive. The average effect of giving feed additives can be seen in Table 01 and Figure 01. 
Table 01: Effect of feed additive of the protein consumption, body weight gain, protein conversion and meat protein conservation of broiler

\begin{tabular}{lrrrr}
\hline \multicolumn{1}{c}{ Variables } & \multicolumn{1}{c}{$\mathrm{P}_{0}$} & \multicolumn{1}{c}{$\mathrm{P}_{1}$} & \multicolumn{1}{c}{$\mathrm{P}_{2}$} & \multicolumn{1}{c}{$\mathrm{P}_{3}$} \\
\hline Protein consumption & $616.86^{\mathrm{c}}$ & $558.28^{\mathrm{b}}$ & $531.08^{\mathrm{b}}$ & $501.07^{\mathrm{a}}$ \\
Body weight gain & $1328.6^{\mathrm{a}}$ & $1505.7^{\mathrm{b}}$ & $1555.7^{\mathrm{b}}$ & $1268.8^{\mathrm{a}}$ \\
Protein conversion & $0.43^{\mathrm{b}}$ & $0.37^{\mathrm{a}}$ & $0.34^{\mathrm{a}}$ & $0.40^{\mathrm{b}}$ \\
Meat protein conversion & $0.56^{\mathrm{b}}$ & $0.50^{\mathrm{a}}$ & $0.46^{\mathrm{a}}$ & $0.57^{\mathrm{b}}$ \\
\hline
\end{tabular}

Note : The similar superscript in the same row show non significant difference $(P>0.05)$.

$P_{0}$ (basal ration without a mixture of red ginger and turmeric meal), $P_{1}(0.5 \%$ mixture red ginger mixture + turmeric meal $), P_{2}(1 \%$ mixture red ginger mixture + turmeric meal $)$ and $P_{3}(1.5 \%$ mixture red ginger mixture + turmeric meal $)$

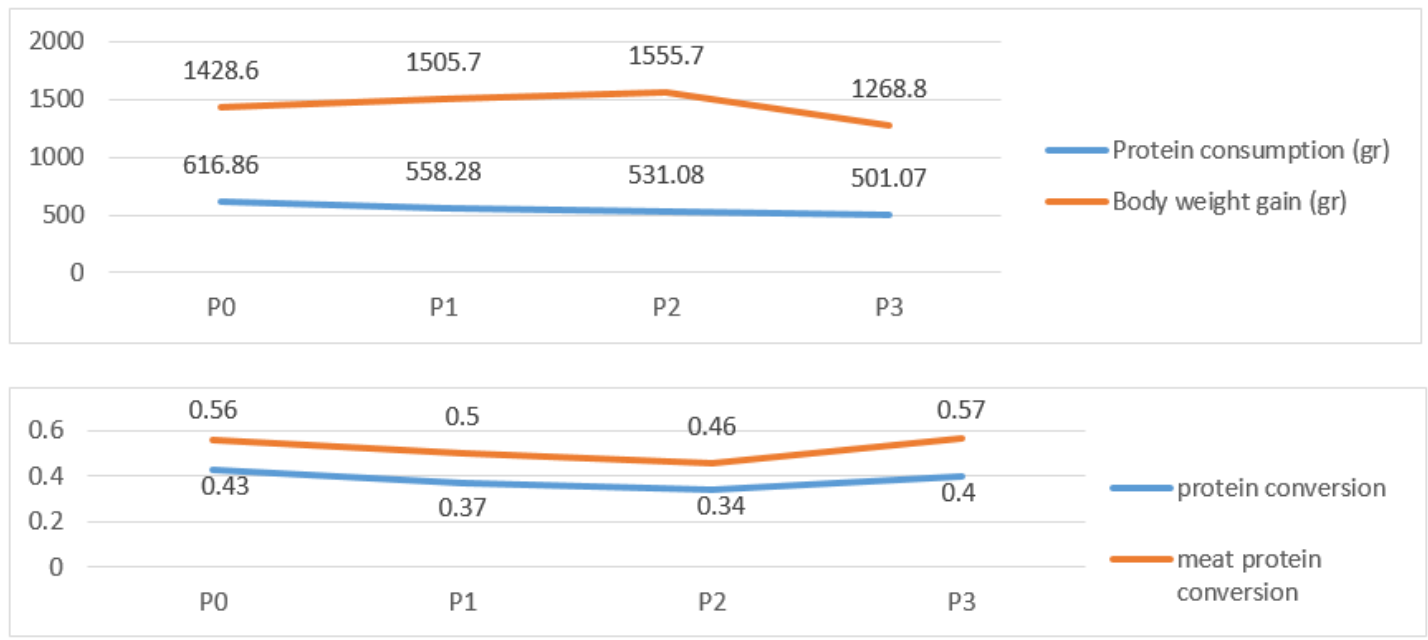

Figure 01: Influence of mixed red ginger (zingiber offinale var rubrum) and turmeric (curcuma longa) in the ration on conversion meat protein broiler

\section{Protein consumption}

The addition of a mixture of red ginger and turmeric meal has a significant effect on protein consumption. Protein consumption in treatment P1 and P2 was significantly lower than control treatment. This showed that the higher level of addition of the mixture of red ginger and turmeric in the basal ration will cause the consumption of the ration to decrease and will also affect the consumption of protein. This is due to the bitter taste and the pungent odor so that the palatability of the ration decreases resulting in decreased ration consumption and protein consumption. Protein consumption was influenced by ration consumption while the metabolism of feed ingredients in the digestive tract would affect ration consumption. The better metabolism of feed ingredients in the digestive tract will affect the appetite and feed consumption, consumption of rations increases the consumption of protein as well.
According to the effect of atsiri oils in ginger, they can stimulate the activities of pancreatic enzymes in guts, thus, promoting digestion and absorption leading to high weight gain in broiler chickens. Rialita et al, (2015) added that the compounds in essential oils derived from terpenoid compounds play a major role in the antibacterial activity so that mucous membranes can be stimulated in the intestine which results in the stomach becoming empty and the chicken will consume rations. Protein consumption depends on the quality and levels of crude protein in the ration. Chicken feed consumption increases accompanied by an increase in protein consumption. Protein consumption is the amount of protein consumed by poultry depending on the amount of ration consumption. Protein consumption is influenced by feed volume and energy content because the energy content of feed regulates the amount of feed eaten by livestock. Chicken can biologically regulate energy consumption according to its needs, 
otherwise, in certain conditions, the volume will be more important than its energy consumption. Nasir Rajput et al, (2013) added, that dietary supplementation of curcumin enhanced overall growth performance, metabolism and nutrients absorptive area of villi in small intestine, while decreased fat deposition in abdominal area, .

\section{Body weight gain}

Moreover, data in Table 01 and Figure 01 revealed that the administration of a mixture of red ginger extract and turmeric to broilers had a significant effect on weight gain. It appears that the average body weight gain in treatments $\mathrm{P} 1$ and $\mathrm{P} 2$ is significantly higher than treatments $\mathrm{P} 0$ and P3. The addition of a mixture of red ginger and turmeric as much as $0.5 \%$ and $1.0 \%$ gave a positive result on the body weight gain of broiler chickens. Active substances contained in red ginger and turmeric will stimulate the walls of the gallbladder to release bile and stimulate the release of pancreatic sap containing amylase, lipase, and protease enzymes that are useful for improving the digestion of feed ingredients such as carbohydrates, fats, and proteins. Besides, atsiri oils contained in red ginger and turmeric can accelerate the emptying of stomach contents. When the stomach is empty, the level of consumption will increase so that it will produce optimal body weight gain.

These results reinforce the previous assumption that the content of active compounds found in ginger and turmeric play a positive role in improving the performance of broiler chickens. Following opinion by Sudipta et al, (2017) conveys that the administration of ginger extract in broiler chickens significantly increases body weight. Ginger fermentation extract (Zingiber officinale) can increase appetite in broiler chickens because the role of active compounds contained in the ginger rhizome namely oleoresin and gingerol will play a role in stimulating digestive enzymes, especially lipases, disaccharides, and maltosis so that the digestive process will naturally be faster and optimal (Zhang et al., 2015) In the treatment of P3 addition level, 1.5\% can decrease body weight gain. This shows that the red ginger and turmeric contain atsiri oils which if given excessively to broilers the chicken weight gain will decrease. Atsiri oils have a sharp taste and a characteristic odor that can cause palatability to decrease, thus affecting feed consumption, protein consumption, and body weight gain.

\section{Protein conversion}

Data in Table 01. and Figure 01 showed that the average protein conversion in each treatment ranged from 0.34 to 0.43 . Conversion protein values in the $\mathrm{P} 1$ and $\mathrm{P} 2$ treatments were significantly lower compared to the P0 and $\mathrm{P} 3$ treatments. This shows that $\mathrm{P} 1$ and $\mathrm{P} 2$ treatments are more efficient in using the protein consumed to produce weight gain compared to $\mathrm{P} 0$ (control ration) and $\mathrm{P} 3(1.5 \%$ mixture of red ginger + turmeric meal). By giving mixture red ginger + turmeric meal in the ration the higher the level can reduce the palatability of the ration. Decreased palatability greatly affects feed consumption and protein consumption as well as broiler chicken body weight gain so that it has an impact on the value of the resulting protein conversion. Palatability reduction is possible because fitofarmaka contains essential oils with distinctive aromas and flavors when added to the ration at a higher level. The use of herbal feed additives exceeding $1 \%$ can have a negative impact on livestock (Karangiya et al., 2016). The impact caused by too high a dose causes the value of protein conversion produced by P3 treatment to increase.

\section{Meat protein conversion}

The administration of a mixture of red ginger and turmeric meal to broiler chickens had a significant effect on the value of meat protein conversion (Table 01 and Figure 01). The average protein conversion value in each treatment ranges from 0.46 to 0.57 . The average protein conversion value in the treatment of $\mathrm{P} 1$ $(0.5 \%$ mixture of red ginger and turmeric meal and P2 (1\% mixture of red ginger and turmeric meal) was significantly lower compared to (P0), and (P3). This gives understanding that P1 and $\mathrm{P} 2$ are more efficient in using the protein consumed to produce meat, and this is caused by the active ingredient of curcumin, atsiri oils, and oleorisin contained in turmeric meal and red ginger meal which can stimulate digestive 
enzymes and inhibit the growth of pathogenic bacteria. The addition of red ginger rhizome meal and turmeric will indirectly affect the consumption of feed and absorption of food substances so that it can produce increased meat production. According to A. Kafi et al, (2017) said that the higher the content of ginger and turmeric in the ration the higher the effect of the produced colagoga and will stimulate bile to secrete bile as a result of digestion protein, and carbohydrates are more efficient and will ultimately lead to the production of meat produced.

\section{CONCLUSIONS}

Research showed that the treatment of mixture red ginger and turmeric meal on P1 and P2 were not significantly different from the conversion value of meat protein but the meat protein conversion value significantly lower compared to treatment P0 (basal ration without a mixture of red ginger and turmeric meal) and P3 (1.5\% mixture red ginger and turmeric meal). This results conclude that the use of $1 \%$ mixture of red ginger + turmeric meal $\left(\mathrm{P}_{2}\right)$ in the basal ration as feed additive resulted the best on meat protein conversion value of broiler.

\section{Data Availability Statement}

The datasets generated during and or analysed during the current study are available from the corresponding author on reasonable request.

\section{ACKNOWLEDGMENTS}

The author would like to thank Dani Garnida, Wiwin Tanwiriah, Roostita L. Balia for conducting this research.

\section{REFERENCE}

A. Kafi, M.N., Uddin, M.J., Uddin, M.M.H., Khan and M.E. Haque. (2017). Effect of dietary supplementation of turmeric (curcuma longa), ginger (zingiber officinale) and their combination as feed additives on feed intake, growth performance and economics of broiler, International Journal of Poultry Science. 16 (7) : 257-265. DOI: https://doi.org/10.3923/ ijps.2017.257.265

Indrawati Y. Asmara., Tuti Widjastuti., Iwan Setiawan., Abun., Ruhyat Partasasmita. (2018). The growth performances and the gut health parameters of sentul chicken supplemented with a various dosage of tumeric powder, Nusantara Bioscience ISCA Journal of Biological Science. 10(3) : 2087-3948. DOI: https://doi.org/10.13057/nusbiosci/n100301

Karangiya, V. K., H. H. Savsani., Shrikant Soma P., D. D. Garg., K. S. Murthy., N. K. Ribadiya and S. J.Vekariya. (2016). Effect of dietary supplementation of garlic, ginger and their combination on feed intake, growth performance and economics in commercial broilers, Veterinary World. 9 : 245 - 25. DOI: https://doi.org/10.14202/vetworld.2016.245-250

Kunnumakkara, A.B., Bordoloi, D., Padmavathi, G, Monisha., J, Roy, N.K., Prasad, S, Aggarwal., B.B. (2017). Curcumin, the golden nutraceutical: Multitargeting for multiple chronic diseases, Br. J. Pharmacol. 174 : 1325-1348. DOI: https://doi.org/10.1111/bph.13621

Nasir Rajput., Naeem Muhammad., Rui Yan., Xiang Zhong and Tian Wang. (2013). Effect of dietary supplementation of curcumin on growth performance, Intestinal morphology and nutrients utilization of broilers chick, Journal of Poultry Science. 50 : 44-52. DOI: https:// doi.org/10.2141/jpsa.0120065 
Rialita, T., W.P. Rahayu., L. Nuraida \& B. Nurtama. (2015). Antimicrobial activity of red ginger (zingiber officinale var. rubrum) and red galangal (alpinia purpurata k. schum) essential oils against pathogenicand food spoilage bacteria, Journal Agritech. 35(1) : 43-52. DOI: https:// doi.org/10.22146/agritech.9418

Sudipta Talukder., Md. Mehedi Hasan., Zakaria Al Noman., Yousuf Ali Sarker., Torun Kumar Paul and Mahmudul Hasan Sikder. (2017). Effect of dietary supplementation of ginger extract on growth, carcass characteristics and haematological parameters in broilers, Asian Journal of Medical and Biological Research. 32 : 211-215. DOI: https://doi.org/10.3329/ajmbr. v3i2.33571

Tuti Widjastuti., Iwan Setiawan., Abun. (2017). The use of turmeric (curcuma domestica val) meal in the rational feed additive on hen-day production and egg quality of sentul chicken, Scientific Papers Series D. Animal Science Volume Lx : 131-135.

Z.A. Sa'aci., O.J. Alabi., D. Brown and J.W. Ng'ambi. (2018). Effect of aqueous ginger (zingiber officinale) extract on growth performance, nutrient digestibility and economy of feed conversion of broiler chickens, Animal Nutrition and Feed Technology. 18 : 225-231. DOI: https://doi.org/10.5958/0974-181x.2018.00021.5

Zhang. G. F., Yang. Z. B., Wang. Y., Yang., W. R., Jiang., S. Z. And Gai. G. S. (2015). Effects of ginger root (Zingiber officinale) processed to different particle size on growth performance, antioxidant status, and serum metabolites of broiler chickens, Journal of Poultry Science. 88 : 2159-2166. DOI: https://doi.org/10.3382/ps.2009-00165 